\title{
Economic and environmental effects of Integrated Pest Management program: A case study of Hau Giang province (Mekong Delta)
}

\author{
Lợi ích kinh tế và môi truờng khi áp dụng chuơng trình quản lý dịch hại tổng \\ hợp IPM: Nghiên cứu điển hình ở tỉnh Hậu Giang (Đồng bằng sông Cửu Long) \\ Research article
}

Nguyen Trung Dung ${ }^{1,2} *$

${ }^{I}$ Thuy loi University, Ha Noi; ${ }^{2}$ M\&E team of WB project for Mekong Delta Water Management for Rural Development

\begin{abstract}
Since many years, the agro-technical programs such as "3 reduction 3 increase", " 1 must 5 reduction" and System of Rice Intensification (SRI) have been carried out with definite results. Recently, IPM program (integrated pest management) - a more comprehensive measure (using all possible techniques and methods to keep the pest populations below a level causing economic injury) has been firstly piloted on a large scale in the Mekong Delta. This paper presents the main results of piloting IPM program in 2,610 hectares during 2014-2017 in Hau Giang province. As results, farmers have better economic benefit in production; the quality of rice has been gradually improved and can overcome the technical barriers of advanced countries in rice trade such as US, EU and Japan. In addition, the environmental and ecological consequences can be avoided due to overuse of fertilizer and pesticide. Field ecosystems will be gradually restored.
\end{abstract}

Tù̀ nhiều năm nay nhũng chuoong trình kỹ thuật nông nghiệp nhu "3 giảm 3 tăng", "1 phải 5 giảm" và hệ thống canh tác lúa cải tiến (SRI) đã được áp dụng và đã có những kết quả nhất định. Còn chuơng trình quản lý dịch hại tổng hợp IPM - một biện pháp tổng hợp và tích cực hơn (sử dụng tất cả các kỹ thuật và biện pháp thich hợp có thể được, nhằm duy trì mật độ của các loài gây hại duới mức gây ra nhũng thiệt hại kinh tế) - được thực nghiệm đầu tiên trên diện rộng ở Đồng bằng sông Cửu Long. Bài báo này trình bày nhũng kết quả chính trong thư nghiệm ở 2.610 ha lúa trong thời gian 2014-2017 ở ở tỉnh Hậu giang. Kết quả là quản lý dịch hai ở nguõong cho phép, người nông dân có lợi hơn về kinh tế trong sản xuất, chất luợng gạo tùng bước được cải thiện và có khả năng vuợt qua các hàng rào kỹ thuật trong thuơng mại lúa gạo của các nuớc tiên tiến nhu USA, châu Âu, Nhật Bản. Ngoài ra tránh được hệ quả về môi truờng sinh thái do sủ dụng quá mức phân bón hóa học và ô nhiếm do thuốc bảo vệ thực vật và hệ sinh thái đồng ruộng dần được phục hồi.

Keywords: Economic and environmental benefits, IPM Integrated Pest Management Program, fertilizer and pesticide residue

\section{Introduction}

Vietnam has about 9.3 million hectares of arable land, and the largest area is the rice cultivation with 4 million hectares (about $45 \%$ of total). It is a miracle that Vietnam's agriculture has undergone a miraculous revolution after 30 years of "Đổi mới" (Renovation), turning a food scarcity into the second largest rice exporter in the world. It must be noted that Vietnam was an important rice exporter worldwide even in the French colonial period and then in the South Vietnam until 1962 [9]. In 2017, the total export volume will reach 4.9 million tons. Rice is mainly exported to Asia (68.41\%, of which $40 \%$ to China), followed by Africa $14.93 \%$ (Figure 1 and 2). Compared to Thailand, the largest rice exporter in the world, in 2013 Vietnam exported 6.68 million tons and the FOB value is 2.893 billion USD [10], however Thailand had 6.749 and 4,172 respectively. The reason is that Thai rice has better quality and brand. So thus, Vietnam has to change the current rice production status: high productivity, low price, low quality, environmental pollution and stressing of land and water resources. In 2017 the government issued the new Strategy for development of Vietnam's 
rice export market in the $2017-2020$ period, direction to $2030{ }^{*}$

In last decades, Vietnam's rice has been exporting to "easy" (also low quality/standard) markets like China and Africa. In countries with high export requirements such as United States, Japan and EU require high quality rice and even forbid the import of rice containing pesticide and fertilizer residuals. According to the Vietnam Food Association (VFA), only within the first four months of 2017, more than 1,700 tons rice were rejected by importers. The rejected rice includes jasmine aromatic rice, jasmine broken rice, brown rice and high quality white rice. The rice shipment was rejected by United States because some pesticides in this country do not yet have regulations on the maxium amount of pesticide residue [8]. This is the main reason for the significant change in rice production. Food safety and healthy nutrition are in line with global trends in the 21 st century.

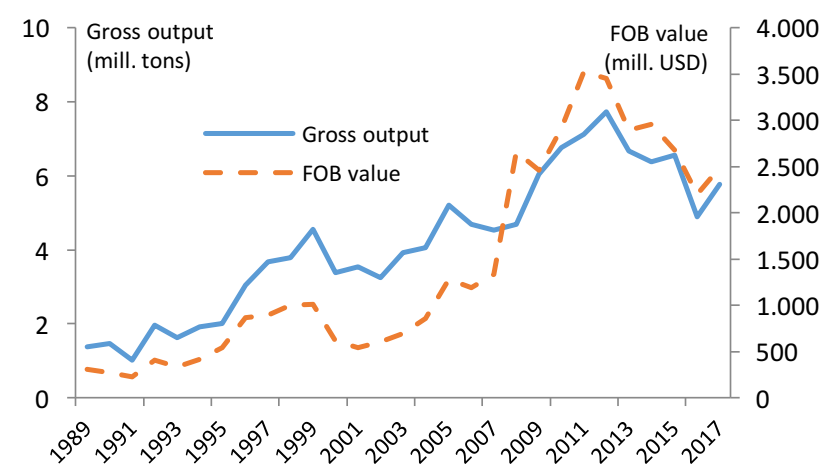

Figure 1. Rice export of Vietnam, 1989-2017 (VFA)

Facing with that situation for many years, in order to improve rice productivity and quality, farmers in Mekong Delta (MD) have been applying the agro-technical measure of "3 reductions 3 increases" (Vietnamese: 3 giảm 3 tăng, shorted $3 \mathrm{G} 3 \mathrm{~T}$ ), initially bring many benefits. ${ }^{\dagger}$ Some time later, MARD issued "1 must 5 reductions" (Vietnamese: 1 phải 5 giảm, shorted $1 \mathrm{P} 5 \mathrm{G}) .^{\ddagger}$ This agrotechnical advance in rice production should overcome the limitations of 3G3T. In 2007 MARD also regonized SRI (System of Rice Intensification, Vietnamese: hệ thống thâm canh lúa cải tiến) as agro-technical measure based on Decree 3062/QĐ-BNN-KHCN. Since 2000 Integrated Pest Management Program (Vietnamese: Quản lý dịch hại tổng hợp, shorted: IPM) was firstly introduced in

\footnotetext{
* In term of the Strategy for development of Vietnam's rice export market in the 2017-2020 period, direction to 2030 following targets are: (a) Reduction of export quantity, but increase of export value, (b) Restructuring of export goods, (c) Increase of direct export with the Vietnamese rice brand, (d) Adapted market structure (strengthening of exports to United States, EU and Australia) [12].

$\dagger$ "3 reductions 3 increases" means: "3 reductions" in rice production is required to reduce: seed sowing, reduce pesticide, and reduce nitrogen. "3 increases" is to increase the rice yield, the rice quality and economic efficiency.

* The "1 must, 5 reductions" means: "1 must" is to use certified seed, "5 reductions" is to reduce seed sowing, nitrogen, pesticide, irrigation water and post harvest losses.
}

North Vietnam. This program is more comprehensive and effective than previous measures.

Concerning the definition of FAO [3], IPM is "the practical manipulation of pest populations using sound ecological principles to keep pest populations below a level causing economic injury". The emphasis here is "practical" and "ecological". In IPM program pesticides are used in combination with other crop management approaches to minimize the effects of pests while supporting a profitable system that has negligible negative effects. IPM has four basic principles: (1) Healthy plantings, (2) Conservation of natural enemies, (3) Frequent field visits, (4) Farmers becoming experts. IPM/FAO has paid attention not only to the natural, environmental and technical environment, but also to the social factors in the IPM application. Farmers are the decision makers for technical measures, so they need to be trained in technical, training and collective skills through the FFS (Farmer Field School).

This paper is dealing with the results and issues when piloting IPM program in Hau Giang province, one of twelve provinces of MD, as a part of WB-project "Mekong Delta Water Management for Rural Development", during 2014-2017.

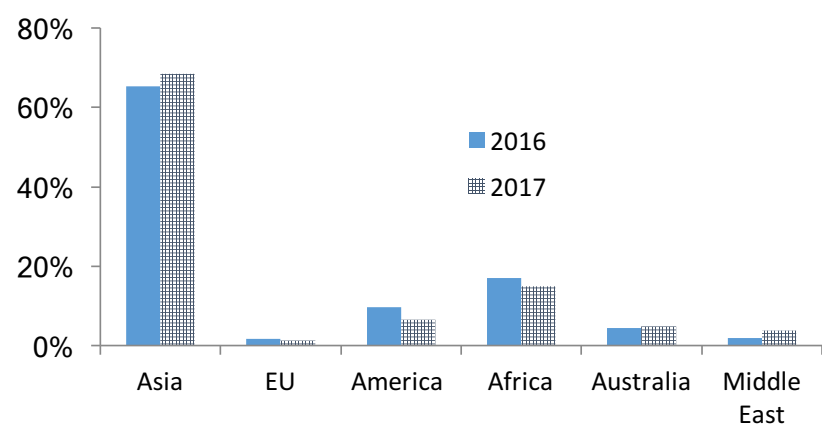

Figure 2. Export rate of rice by region

\section{Materials and methods}

\subsection{Data}

Hau Giang is an agricultural province with an agricultural area of 134,000 hectares, of which 82,000 hectares are for rice cultivation by 76,300 households $(\mathrm{HH})$. Rice is the main crop and makes the main income for Hau Giang farmers. One of the favorable conditions for rice production is the O Mon - Xa No irrigation system, so called a "rice road" in Hau Giang region. It helps not only to irrigate the paddy fields, but also to promote the trade between provinces in MD. The pilot area located in O Mon - Xa No irrigation system, in North of Xa No area with 18,000 hectares (of which 13,000 hectares for rice), consists of communes, districts and towns (Table 1). 2,610 hectares were in pilot, of which 360 hectares for IPM implementation and 2,250 hectares for replication. The targets and contents of this study are in Table 2.

All quantitative and qualitative data of the seven contents mentioned in Table 2, are used for the analysis and evaluation of this testing program. In addition, the secondary 
data of General Statistics Office of Vietnam, MARD, World Band and DARD of Hau Giang were applied.

Table 1. Pilot area

\begin{tabular}{lll} 
\# & District/City & Commune/district/town \\
\hline 1 & Chau Thanh & Tan Hoa, Bay Ngan town, Mot \\
& A & Ngan town, Nhon Nghia A, Truong \\
& & Long A, Truong Long Tay. \\
2 & Vi Thuy & Vi Binh, Vi Dong, Vi Thanh \\
3 & Vi Thanh city & Vi Tan, Phuong 4
\end{tabular}

\subsection{Methods}

The main method used in this study is the implementation of IPM program in different steps, field observation in the pilot area, and statistical comparison between Begin and End of IPM program (see \#1 in Table 2). Begin of IPM (shorted Begin IPM) means Autumn Winter season (AW) 2014 and Winter Spring (WS) 2014-15; End of IPM (shorted End IPM) is AW 2016 and WS 2016-17. The weather and seasonal developments at the Begin and End IPM were nearly similar and not significant.

Two extensive baseline surveys were carried out: (1) Baselinesurvey at Begin IPM: Randomly selected 500 farmers in the project area, interviewed directly by using the household questionnaire; (2) Baselinesurvey at End IPM: Select $80 \%$ of the IPM-trained farmers and $20 \%$ of the non-IPM-trained farmers (still in project area). It enables the evaluation of effectiveness of IPM program (comparison between pre- and post-implementation phas- es as well as between farmers with and without IPMtraining. SPSS softeware was applied for analysis.

\section{Results and discussion}

\subsection{General information}

Information on famers and households participed in pilot project: There is no difference between Begin and End IPM concerning the age, ethnicity and gender, education, farming experienes: (1) Age group of farmers surveyed varies between 31-55 (Begin IPM 67\%, End 61.8\%); (2) Ethnicity and gender: The Kinh group is more prevalent than the Khmer and Chinese (only 1-2\%); (3) Gender: The percentage of male is higher than female (Begin \& End IPM 86.8\% \& 87.6\% respectively); (4) Education: Most of surveyed farmer finished the secondary school (Begin \& End IPM 52\% \& 46\% respectively), the primary school (15\% \& 36\% respectively); (5) Farming experiences: Experiences can help farmers better to understand land, soil, plants and weather in the production site. Farming experience combined with advanced cultivation techniques is very effective in production. The farmers in the project area have 10-30 years experiences (Begin and End IPM $66 \%$ \& 55\% respectively).

Land ownership: The total area of 500 households surveyed at Begin IPM are 746.59 ha and End IPM 732.86 ha. Most famers cultivated on your own field (Begin IPM 98\%, End 99.4\%). The HH's average land area for rice cultivation in both cases is around 1.47-1.49 ha.

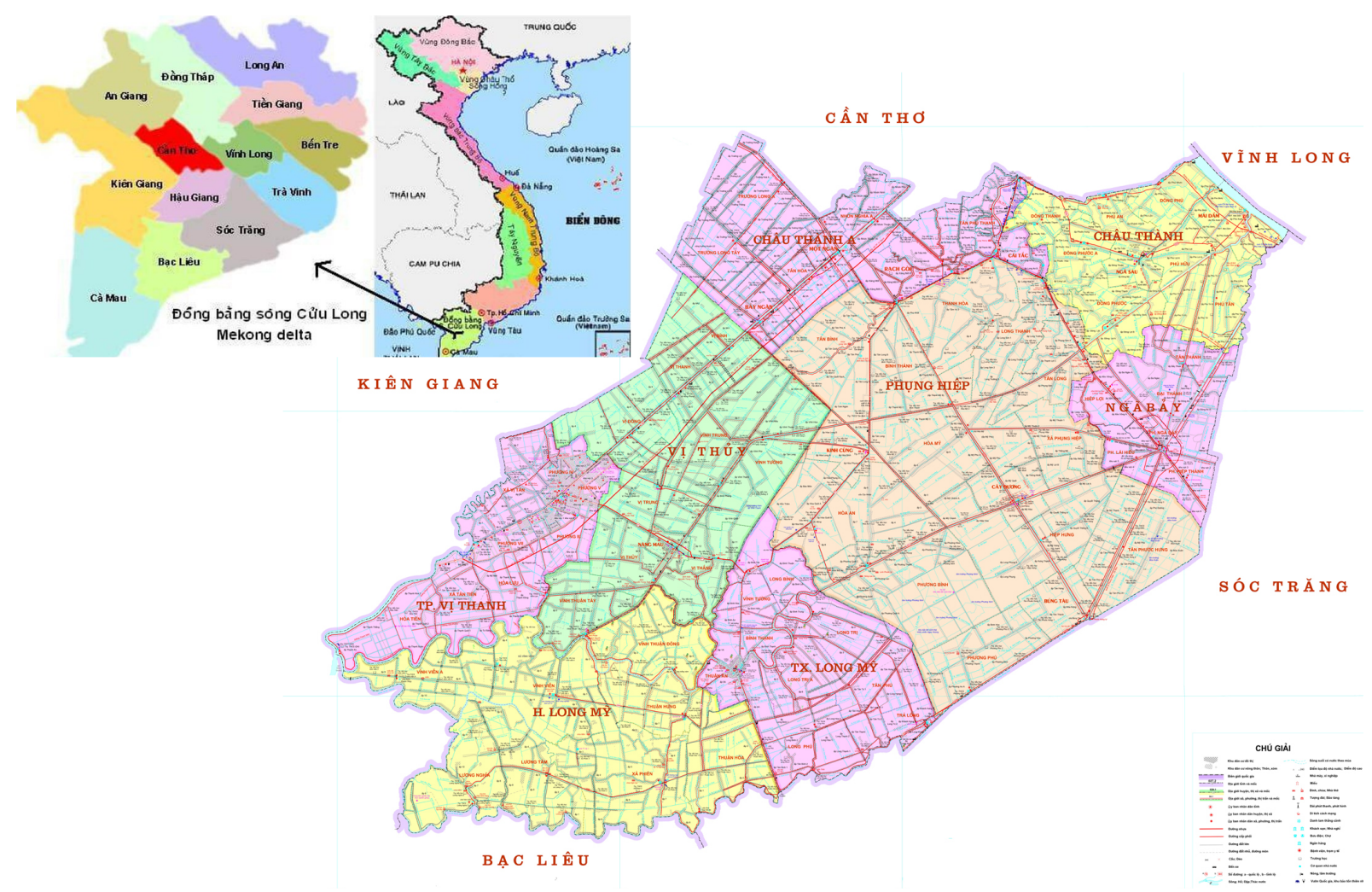

Figure 3. The administrative map of Hau Giang province ${ }^{\S}$

\footnotetext{
${ }^{\S}$ Source: http://www.haugiang.gov.vn/Portal/data/sites/1/map/map.htm
} 
Table 2. Targets and contents of IPM program in Hau Giang province

\begin{tabular}{ll} 
\# & Contents/steps \\
\hline 1 & Baseline survey (Begin and End of piloting IPM program) \\
2 & Training for farmers in IPM, SRI, 3G3T and 1P5G \\
3 & Grouping the key farmers (5 farmers per group) \\
4 & Advanced training for technicians \\
5 & Training for the owners of fertilizer \& pesticide shops and agents \\
6 & Storage tank for pesticide packaging after use \\
7 & Area in IPM program with the target: reduction of $50 \%$ of pesticide \\
& and 10\% of nitrogenous fertilizer
\end{tabular}

$\begin{array}{cr}\text { Unit } & \text { Quantity } \\ \text { Times } & 02 \\ \text { Farmer } & 2,970 \\ \text { Group } & 10 \\ \text { Technician } & 300 \\ \text { Agent/shop for pesticide } & 300 \\ \text { Storage tank/container } & 90 \\ \text { Hectars } & 2,610\end{array}$

Number of rice pacells per $H H$ is im average 1.25 ha (minimum 0.1 ha and maximum $6.7 \mathrm{ha}$ ). ${ }^{* *}$ This area is quite large compared to the north and central region, which facilitates the cultivation of rice, fertilizers and pesticide application.

Rice variety and seeding: As the rice varieties shown in Table 3, IR 50404 has highest ratio in Begin and End IPM. This variety is preferred by farmers because of short growing duration (only 90-95 days after sowing), ensuring 3 crops per year, hahaving high yield and easy cultivation. However, the rice price is much lower than jasmine 85. The specialized agencies such as "khuyến nông" (agriculture extension) have recommended to change the seed structure and to limit this variety. At End IPM, there is a change in the variety structure, especially OM 5451 rice, which has high quality, stable breed characteristics and higher selling price than IR 50404.

Table 3. Rice varieties in Begin and End IPM

\begin{tabular}{lrrrr} 
Rice & \multicolumn{2}{c}{ WS (\%) } & \multicolumn{2}{c}{ AW (\%) } \\
variety & Begin & End & Begin & End \\
\hline IR 50404 & 63.4 & 60.6 & 69.0 & 52.4 \\
Jasmine 85 & 9.8 & 3.2 & 2.6 & - \\
OM 5451 & 18.8 & 33.2 & 18.0 & 45.8 \\
OM 4218 & 3.2 & 1.4 & 6.0 & - \\
OM 4900 & 2.2 & - & 0.8 & - \\
Other* & 2.6 & 1.6 & 3.6 & 1.8 \\
Total & 100 & 100 & 100 & 100
\end{tabular}

Thus, OM 5451 increased in WS season from $18.8 \%$ to $33.2 \%$. This means that farmers in the project area are better aware of the economic benefits of new rice varieties. It should be noted that recently in MD varieties such as Jasmine 85, RVT, AP 2010 ... are also more popular. Although the length of growing period of 105-115 days, but these varieties are suitable for alluvial or slightly alkaline soils, have a good rice price and reach the export standards.

Seeding density and method: Concerning the survey results, in the project area there are two seeding methods: manual seeding and seeding in row. $85 \%$ of farmers still applied manual seeding. At the End IPM the ratio of seeding in row is lightly increased. This is why the seeding density in the project area at Begin and End IPM is still high in comparison with the current recommended level of $80-120 \mathrm{~kg} / \mathrm{ha}$ (Table 4$)$.

\footnotetext{
** The arable land per capita in Vietnam is 0.16 ha in $1961,0.07$ ha in 2015 (WB data)
}

Table 4: Seeding density - Begin and End IPM

\begin{tabular}{|c|c|c|c|c|}
\hline \multirow{2}{*}{$\begin{array}{l}\text { Seeding densi- } \\
\text { ty } \\
\text { (kg/ha season) }\end{array}$} & \multicolumn{2}{|c|}{ WS } & \multicolumn{2}{|c|}{$\mathbf{A W}$} \\
\hline & Begin & End & Begin & End \\
\hline $80-120$ & $2.6 \%$ & $10.4 \%$ & $1.8 \%$ & $2.4 \%$ \\
\hline $121-200$ & 62.2 & 84.4 & 56.6 & 84.2 \\
\hline$>200$ & 35.2 & 5.2 & 41.6 & 13.4 \\
\hline Max/Min & $350 / 80$ & $300 / 80$ & $300 / 100$ & $300 / 100$ \\
\hline Average & 199.7 & 175.1 & 205.7 & 177.1 \\
\hline Std-diviation & 1.83 & 1.42 & 1.88 & 1.45 \\
\hline
\end{tabular}

\subsection{Pesticides and diseases: Situation and treatment}

\subsubsection{Pests and pesticide use}

Table 5 shows the spray frequency at Begin and End IPM. In both seasons WS and AW at End IPM it is a clear reduction of spraying against Stenchaetothrips biformis (bo trĩ) was recorded $(17 \% \& 31.9 \%$ ). Orseolia oryzae (muối hành) developed widely in $\mathrm{Vi}$ Thuy and Chau Thanh district due to the favorable weather conditions (hot and high humidity) so that the spray frequency at End IPM was higher than Begin IPM (10.3\% in WS and $7.1 \%$ in $\mathrm{AW}$ ). In the case of Cnaphalocrosis medinalis $\mathrm{G}$, there is a small reduction in WS season $(40.4 \%$ and $38.7 \%)$, but increasing in AW (16.8\% and $21 \%)$. Concerning the recommendation, spray against Nilaparvata lugens Stal (Rầy nâu), Cnaphalo-crosis medinalis G (Sâu cuốn lá) should be limited within 40 days after sowing. During pilot phase, the farmers followed this recommendation. Smiley (Nhện gié) is always a big problem and the treatment should be in advance. Therefore, the treatment frequency increased at End IPM (11.3\% in WS and $12.8 \%$ in AW).

Table 5. Frequency of pesticide application

\begin{tabular}{|c|c|c|c|c|}
\hline \multirow{2}{*}{ Pests } & \multicolumn{2}{|c|}{ WS (\%) } & \multicolumn{2}{|c|}{ AW (\%) } \\
\hline & Begin & End & Begin & End \\
\hline $\begin{array}{l}\text { Stenchaetothrips } \\
\text { biformis }(B o \text { trĩ) }\end{array}$ & 22.6 & 17.0 & 33.2 & 31.9 \\
\hline $\begin{array}{l}\text { Leptocorisa vari- } \\
\text { cormis (Bo xit hôi) }\end{array}$ & 0.2 & 3.4 & 0.1 & 0.1 \\
\hline $\begin{array}{l}\text { Orseolia oryzae } \\
\text { (muỗi hành) }\end{array}$ & 0.1 & 10.3 & - & 7.1 \\
\hline $\begin{array}{l}\text { Steneotarsonemus spinki } \\
\text { Smiley (Nhện gié) }\end{array}$ & 9.6 & 11.3 & 7.2 & 12.8 \\
\hline $\begin{array}{l}\text { Nilaparvata lugens } \\
\text { Stal }(\text { Rầy nâu) }\end{array}$ & 21.2 & 13.7 & 32.7 & 14.8 \\
\hline $\begin{array}{l}\text { Mythimana separata } \\
\text { Walker (Sâu cắn gié) }\end{array}$ & 0.2 & 0.3 & 0.4 & 3.6 \\
\hline Cnaphalocrosis medi- & 40.4 & 38.7 & 16.8 & 21.0 \\
\hline
\end{tabular}




\begin{tabular}{|c|c|c|c|c|c|c|c|c|c|}
\hline \multirow{2}{*}{ Pests } & \multicolumn{2}{|c|}{ WS (\%) } & \multicolumn{2}{|c|}{$\mathbf{A W}(\%)$} & \multicolumn{5}{|c|}{ Table 7. The number of spray or pesticide application } \\
\hline & Begin & End & Begin & End & \multirow[b]{2}{*}{ Diseases } & \multicolumn{2}{|c|}{ WS (\%) } & \multicolumn{2}{|c|}{ AW (\%) } \\
\hline nalis G (Sâu cuốn lá) & & & & & & Begin & End & Begin & End \\
\hline Scirpophaga incertulas & 5.8 & 5.1 & 7.9 & 4.8 & HH surveyed & 500 & 500 & 500 & 500 \\
\hline Walker (Sâu đục thân) & & & & & Mean of pes- & $7.54 \pm$ & $6.85 \pm$ & $7.79 \pm$ & $6.7 \pm$ \\
\hline $\begin{array}{l}\text { Nymphula depunctalis } \\
\text { (Sâu phao đục be ) }\end{array}$ & - & - & 1.6 & 3.9 & $\begin{array}{l}\text { ticide applica- } \\
\text { tion }\end{array}$ & 2.1 & 2.5 & 2.1 & 2.7 \\
\hline Total & 100 & 100 & 100 & 100 & Std. deviation & 0.09 & 0.11 & 0.10 & 0.12 \\
\hline
\end{tabular}

Table 6 shows that most farmers sprayed against Pyricularia oryzae in leaf, haulm, coreless grain (đạo ôn lá, cổ bông, lép hạt, đốm vằn). In addition, within the growing phase, at least 02 times must be sprayed as preventative measures (before and after flowering). In reality, the weather pressure and pathogens were also reasons for additional sprays against these diseases. Similarly was the disease coreless grain. Some reductions of treatment quantity are in Table 6.

Table 6. Spray frequency for disease treatment

\begin{tabular}{|c|c|c|c|c|}
\hline \multirow{2}{*}{ Diseases } & \multicolumn{2}{|c|}{ WS (\%) } & \multicolumn{2}{|c|}{ AW (\%) } \\
\hline & Begin & End & Begin & End \\
\hline Pyricularia oryzae & & & & \\
\hline $\begin{array}{l}\text { Cav. (đạo ôn lá, cổ } \\
\text { bông) }\end{array}$ & 47.7 & 31.5 & 46.4 & 47.20 \\
\hline $\begin{array}{l}\text { Bacterial leaf blight } \\
\text { disease (Bac lá/cháy } \\
\text { bia lá) }\end{array}$ & 7.9 & 23.0 & 8.7 & 16.5 \\
\hline $\begin{array}{l}\text { Root Knot Nematode } \\
\text { (Bưóu rễ) }\end{array}$ & 0.1 & - & - & - \\
\hline Rhizoctonia solani & & & & \\
\hline $\begin{array}{l}\text { Kuhn (Đốm vằn/khô } \\
\text { vằn) }\end{array}$ & 10.3 & 11.9 & 10.4 & 8.5 \\
\hline $\begin{array}{l}\text { Coreless grain (Lem } \\
\text { lép hat) }\end{array}$ & 29.9 & 24.5 & 30.4 & 22.1 \\
\hline $\begin{array}{l}\text { Organic poisoning } \\
(\text { Ngộ độc hũu co') }\end{array}$ & - & 0.4 & 0.1 & 0.2 \\
\hline Vàng lá chín sớm & 3.9 & 8.5 & 4.0 & 5.5 \\
\hline Rice Grassy Stunt & & & & \\
\hline $\begin{array}{l}\text { Virus (Vàng lùn, lùn } \\
\text { xoắn lá) }\end{array}$ & 0.2 & 0.2 & & \\
\hline
\end{tabular}

\subsection{Spray number and amount}

Generally, the spray number is different between Begin and End IPM. A significant reduction was reported at End IPM (Table 7). The spray amount used against pesticides, diseases, snail and mouse, is shown in Table 8. The average amount of pesticides, medicine against diseases, snail and mouse is quite diffent between Begin and End IPM in both seasons. Among five kinds of medicine, the amount of medicine against snail is very high. The difference in the mean values between start and end IPM is statistically significant.

Figure 4 shows the percentage reduction of drugs against herbicides, pesticides, snails, diseases and mice. The reduction of drugs against pesticides and mice is very high and has been well evaluated. However, the reduction rate of the herbicide and the disease is less than $10 \%$. In the future, various agricultural measures will be applied, for example manual weeding.

Table 8. The average medicine amount

\begin{tabular}{|c|c|c|c|c|}
\hline \multirow{3}{*}{$\begin{array}{l}\text { Medicine } \\
\text { against }\end{array}$} & \multicolumn{3}{|c|}{ WS } & W \\
\hline & \multicolumn{4}{|c|}{ (kg or liter/ha) } \\
\hline & Begin & End & Begin & End \\
\hline Herbicide $(c o ̉)$ & 1.09 & 1.01 & 1.13 & 1.01 \\
\hline Pesticide (sâu) & 1.16 & 0.67 & 1.11 & 0.72 \\
\hline Snail $(\hat{o ́ c})$ & 5.51 & 4.72 & 5.67 & $5.32 *$ \\
\hline Disease (bệnh) & 2.79 & $2.65^{*}$ & 2.73 & $2.63 *$ \\
\hline Mouse (chuôt $)$ & 0.48 & 0.31 & 0.99 & 0.37 \\
\hline
\end{tabular}

Note: * no statistical significance by t-test for means

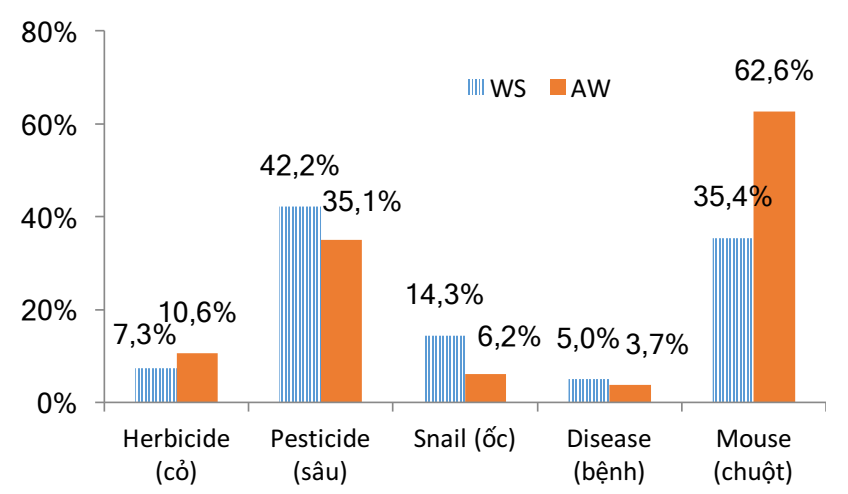

Figure 4. Reduction of herbicide, pesticide at End IPM

Farmers did not use pesticides: The percentage of farmers/HHs do-not-use-pesticide at End IPM higher than Begin IPM in both seasons. This point is very important and HHs, that have idea of combating the pest by using other measures without spray, should be supported. This model should be expanded in the future.

Table 9. Percentages in use $\&$ no use pesticide

\begin{tabular}{lrrrr} 
Farmer/ & \multicolumn{2}{c}{ WS (\%) } & \multicolumn{2}{c}{ AW (\%) } \\
household & Begin & End & Begin & End \\
\hline Use pesticide & 93.0 & 84.8 & 89.6 & 86.8 \\
Do-not-use pesticide & 7.0 & 15.2 & 10.4 & 13.4
\end{tabular}

\subsection{Yield and economic benefits by IPM}

a) WS season: Table 10 shows that the yield class of $6-8$ tons/ha is reducted from $74.8 \%$ (Begin IPM) to $69.8 \%$ (End IPM), while increasing in the class with more than 8 tons/ha. Compared to the Begin IPM, the average yield is 
higher (equivalent $30 \mathrm{~kg} / \mathrm{ha}$ ). Although a small increase only, this effort is highly appreciated. In the testing period 2015-2017, the rice price in the export market was not high. In addition, the variety IR 50404 had a high percentage (also more than 50\% at Begin and End IPM), so that the average price was nearly unchanged $(4,361$ and $4,269 \mathrm{VND} / \mathrm{kg}$ ).

In order to reach the target of IPM program the Plant protection division of district worked close with farmers (also introduction and transfer of cultivation techniques 3G3T, demonstration models for training, meeting for experience exchange between farmer groups, field visit...). As result, the total cost of fertilizers and pesticides reduced by $1,096,450 \mathrm{VND} / \mathrm{ha}$, contributing $30 \%$ reduction in pesticides and $70 \%$ in fertilizer costs.

Table 10. Yield and production cost of WS crop season Variable

\begin{tabular}{|c|c|c|c|}
\hline \multirow[t]{2}{*}{ Valatic } & & Deginis iv & . \\
\hline & $<6,0$ & 3,4 & 2,4 \\
\hline \multirow{5}{*}{$\begin{array}{l}\text { 1. Crop } \\
\text { yield ton/ha }\end{array}$} & $6,0-8,0$ & 74,8 & 69,8 \\
\hline & $>8,0$ & 21,8 & 27,8 \\
\hline & $\operatorname{Max}$ & 10,0 & 10,00 \\
\hline & Min & 4,61 & 5,00 \\
\hline & Average & 7,56 & 7,59 \\
\hline \multirow{7}{*}{$\begin{array}{l}\text { 2. Crop } \\
\text { price (fresh) } \\
(\mathrm{VND} / \mathrm{kg})\end{array}$} & $<4.200$ & 51 & 39,8 \\
\hline & $4200-$ & 47 & 59,8 \\
\hline & 5000 & & \\
\hline & $>5.000$ & 2 & 0,4 \\
\hline & $\operatorname{Max}$ & 6.000 & 5.130 \\
\hline & Min & 3.400 & 3.900 \\
\hline & Average & 4.361 & 4.296 \\
\hline \multirow{3}{*}{$\begin{array}{l}\text { 3. Cost for } \\
\text { plant protec- } \\
\text { tion (VND) }\end{array}$} & $\operatorname{Max}$ & 5.710 .000 & 5.555 .000 \\
\hline & Min & 640.000 & 434.000 \\
\hline & Average & 2.514.538 & 2.150 .440 \\
\hline \multirow{3}{*}{$\begin{array}{l}\text { 4. Fertilizer } \\
\text { cost (VND) }\end{array}$} & $\operatorname{Max}$ & 7.300 .000 & 7.085 .000 \\
\hline & Min & 1.070 .000 & 1.688 .000 \\
\hline & Average & 3.984.311 & 3.251 .920 \\
\hline \multirow{3}{*}{$\begin{array}{l}5 . \text { Total } \\
\text { revenue } \\
\text { (VND) }\end{array}$} & $\operatorname{Max}$ & 63.000 .000 & 47.048 .000 \\
\hline & Min & 18.460 .000 & 20.000 .000 \\
\hline & Average & 32.629 .916 & 33.066.372 \\
\hline \multirow{3}{*}{$\begin{array}{l}\text { 6. Net bene- } \\
\text { fit (VND) }\end{array}$} & $\operatorname{Max}$ & 56.215 .000 & 41.634 .300 \\
\hline & Min & 12.696 .500 & 15.602 .500 \\
\hline & Average & 26.131.067 & 27.664 .011 \\
\hline
\end{tabular}

b) $A W$ season: Table 11 shows that the yield class of $6-8$ tons/ha is increased from $68.6 \%$ (Begin IPM) to $72.4 \%$ (End IPM), in the class with more than 8 tons/ha from $2.2 \%$ to $17.2 \%$. However, the yield at End IPM was lower than Begin IPM (6.87 and 7.02 tons/ha respectively), also $150 \mathrm{~kg} / \mathrm{ha}$ due to unfavorable weather conditions such as: rains, high humidity, more diseases, especially heavy rains during the rice flowering time.

Table 11. Yield and production cost of AW season

\begin{tabular}{lcrr} 
Variable & & Begin IPM & End IPM \\
\hline & $<6,0$ & 29,2 & 10,4 \\
1. Yield & $6,0-8,0$ & $\mathbf{6 8 , 6}$ & $\mathbf{7 2 , 4}$ \\
ton/ha & $>8,0$ & 2,2 & 17,2 \\
& Max & 9,50 & 9,10 \\
& Min & 4,00 & 3,85 \\
& Average & $\mathbf{7 , 0 2}$ & $\mathbf{6 , 8 7}$ \\
\hline
\end{tabular}

\begin{tabular}{|c|c|c|c|}
\hline Variable & & Begin IPM & End IPM \\
\hline \multirow{7}{*}{$\begin{array}{l}\text { 2. Selling } \\
\text { price (fresh) } \\
(\mathrm{VND} / \mathrm{kg})\end{array}$} & $<4.200$ & 39,8 & 16,6 \\
\hline & $4.200-$ & 58,2 & 81,6 \\
\hline & 5.000 & & \\
\hline & $>5.000$ & 2,0 & 1,8 \\
\hline & $\operatorname{Max}$ & 6.200 & 5.500 \\
\hline & Min & 3.700 & 3.000 \\
\hline & Average & 4.281 & 4.310 \\
\hline \multirow{3}{*}{$\begin{array}{l}\text { 3. Cost for } \\
\text { plant protec- } \\
\text { tion (VND) }\end{array}$} & $\operatorname{Max}$ & 5.840 .000 & 4.595 .000 \\
\hline & Min & 640.000 & 279.000 \\
\hline & Average & 2.685.199 & 2.142.881 \\
\hline \multirow{3}{*}{$\begin{array}{l}\text { 4. Fertilizer } \\
\text { cost (VND) }\end{array}$} & Max & 7.210 .000 & 7.500 .000 \\
\hline & Min & 1.740 .000 & 1.720 .000 \\
\hline & Average & 4.138.697 & 3.329.757 \\
\hline \multirow{3}{*}{$\begin{array}{l}5 . \text { Total } \\
\text { revenue } \\
(\mathrm{VND})\end{array}$} & $\operatorname{Max}$ & 46.150 .000 & 48.924 .300 \\
\hline & Min & 16.000 .000 & 17.500 .000 \\
\hline & Average & 30.048.520 & 33.733.957 \\
\hline \multirow{3}{*}{$\begin{array}{l}\text { 6. Net bene- } \\
\text { fit (VND) }\end{array}$} & $\operatorname{Max}$ & 39.675 .000 & 44.642 .300 \\
\hline & Min & 8.465 .000 & 13.795 .000 \\
\hline & Average & 23.224 .624 & 28.261 .320 \\
\hline
\end{tabular}

The cost of fertilizers and pesticides at End IPM was decreased compared to the Begin IPM, the average reduction was $1,351,000 \mathrm{VND} / \mathrm{ha}$, with $40 \%$ reduction in pesticides and $60 \%$ fertilizer. Thanks to increasing rice price from 4,281 to $4,310 \mathrm{VND} / \mathrm{kg}$ and cost reduction of fertilizers and pesticides the farmer earned more (increased from $26,131,067$ to $27,664,011 \mathrm{VND} / \mathrm{ha}$ ).

\subsection{Fertilizer application}

Generally, the application of chemical fertilizer for rice production in Vietnam is very high, only after China [4]. The further tendency is not yet clearly. Vietnam can make the same way as China or gradually reduce like the European countries. In this study, reduction of chemical fertilizer by $10 \%$ was the first step. Table 10 shows the clear reduction of fertilizer $\mathrm{N}$ and $\mathrm{K}_{2} \mathrm{O}$ in both seasons at End IPM. However, the amount of $\mathrm{K}_{2} \mathrm{O}$ is nearly unchanged. The relationship between the total amount of fertilizer and rice yield was analysed by SPSS and the correlation coefficient varies between $-0,11$ to $-0,28$, it means that more chemical fertilizer can not help to increase the yield. Excess fertilizer residues can penetrate into the groundwater or flow into the canal and river and cause pollution.

Table 12. Average amount of chemical fertilizer used

\begin{tabular}{llcc} 
IPM & \multicolumn{3}{c}{ WS $(\mathrm{kg} / \mathrm{ha} /$ season $)$} \\
\cline { 2 - 4 } program & \multicolumn{1}{c}{$\mathbf{N}$} & $\mathbf{P}_{\mathbf{2}} \mathbf{O}_{\mathbf{5}}$ & $\mathbf{K}_{\mathbf{2}} \mathbf{O}$ \\
\hline Begin & $99.2 \pm 20.6$ & $68.6 \pm 22.0$ & $40.1 \pm 20.4$ \\
End & $89.3 \pm 18.1$ & $62.5 \pm 19.5$ & $40.0 \pm 19.0$ \\
& \multicolumn{3}{c}{$\mathrm{AW} \mathrm{(kg/ha/season)})$} \\
Begin & $101.8 \pm 22.7$ & $70.0 \pm 22.6$ & $42.3 \pm 20.8$ \\
End & $91.1 \pm 26.9$ & $62.2 \pm 18.9$ & $40.1 \pm 19.7$
\end{tabular}

\subsection{Participation of farmers in the training on 3G3T, 1P5G, SRI and other}

The survey results show that the percentage of farmers in training on rice cultivation techniques is increased from $53.6 \%$ Begin IPM to $87 \%$ at End IPM. $13 \%$ of farmers have been trained in other projects/courses organized by 
different pesticide companies. Figure 5 shows the percentage of farmers in different training courses. One of the indicators to check the level of knowledge and awareness of farmers after IPM training understands the threshold of pest and disease damage. End IPM 53.8\% of farmer understand the pest's harmfulness threshold, also compared to begin IPM $26.2 \%$.

Figure 6 and 7 show the situation: receiving information on pesticide use and control methods, and sources of information. The percentage of farmers received information on pesticide use from plant protection officers increased and opposite decreased from agent/shop selling pesticide. This is highly appreciated.

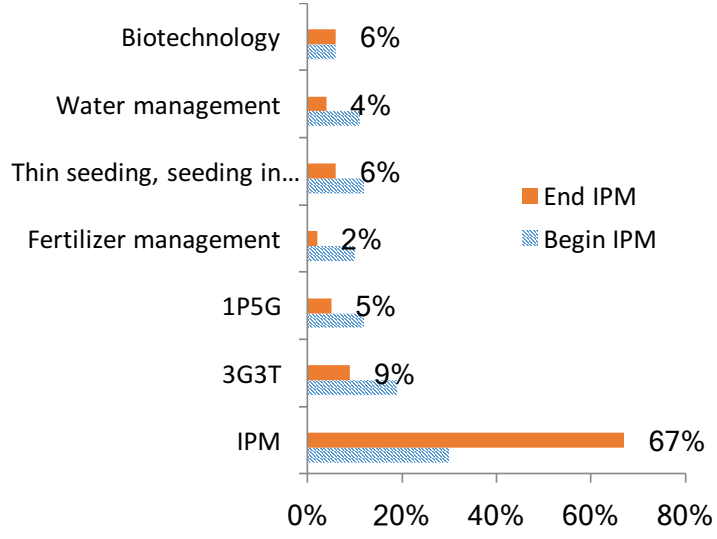

Figure 5. Participation in different training courses

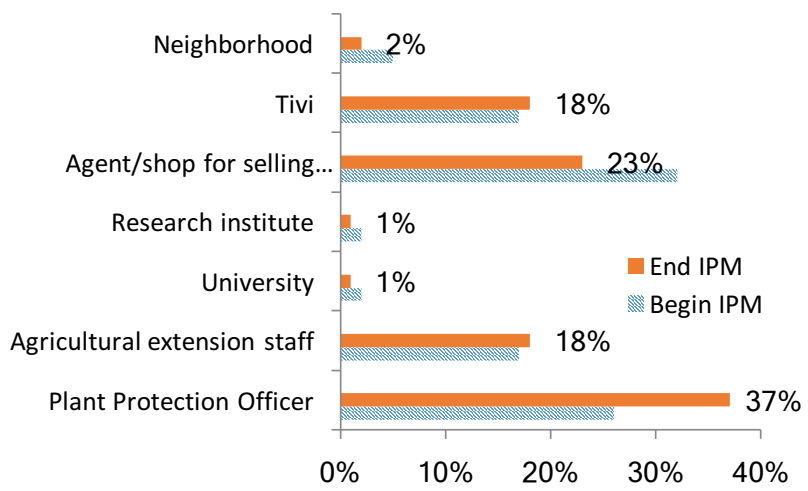

Figure 6. The percentage of farmers receiving information on pesticide use and control methods

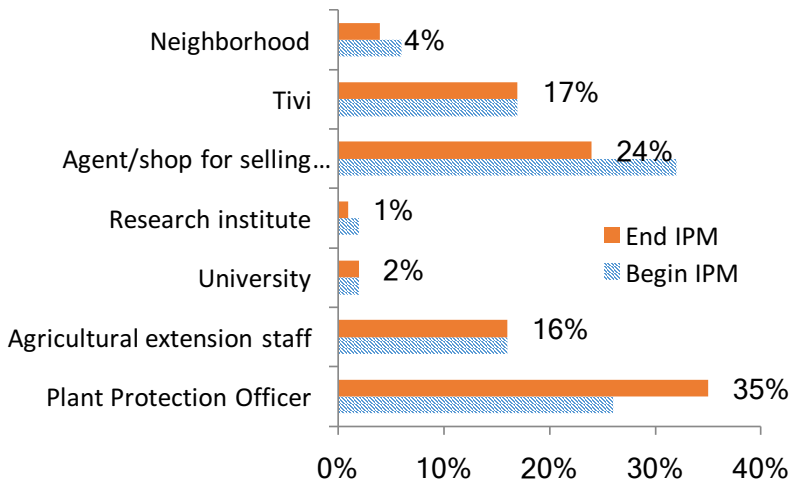

Figure 7. Pesticide use concerning recommendation of sources

The same problem is that farmers use the medicine more under the direction of the plant protection officer, and less after guidance of agent/shop seller. This is rated very positive as sellers always try the pesticide and the fertilizer so much as possible for sale.

\subsection{Gender, labor safety and hazardous waste management}

Gender: Why women did not visit the training courses on rice cultivation which organized by the government's technical staff (staff of the agriculture subdepartment, officers of plant protection division, staff of university and research institute)? The main reasons are: Women have to fullfill your housework (Begin IPM 83.1\%, End $82.7 \%$ ) and additional livestock at home (begin 11.2\% and end $11.1 \%$ ). On the field, women make some jobs like grass picking, soil preparation, rice drying. Very few women do the job like spraying, plowing, etc.

Labour safety: The farmers use more labor protection (masks, caps, protective clothing, gloves, glasses) when spraying pesticides: Begin IPM $84 \%$ and End that $87.4 \%$.

The kinds of sprayer: Begin IPM: $76,7 \%$ of $\mathrm{HH}$ used motorized sprayer, 21\% manual sprayer; End IPM: 75\% and $21.2 \%$ respectively. The manual sprayer is very popular because it is cheaper, but has lower labor efficiency.

Who in charge for spray: Begin IPM: husband (56.7\%), son (14.8\%), hiring (28.5\%); End IPM 48.2\%, 17\% and $34.9 \%$, respectively. The age of hiring people varies between $30-45$ years. Woman in $\mathrm{HH}$ did not normaly participate in spraying.

Clean the sprayer end use and pour the wash water: Farmers have gradually changed their perception of cleaning the sprayer end use and pouring the water. Begin IPM (the rate of rinsing in the field and then dumping the field at End IPM is higher than Begin IPM (Table 13).

Table 13. Cleaning the sprayer after use and pouring the wash water $(\%)$

\begin{tabular}{|c|c|c|c|c|}
\hline & Ho & Field & Pond & Canal \\
\hline \multicolumn{5}{|c|}{ Where does the farmer clean the sprayer? } \\
\hline Begin/end & $11 / 4.4$ & $16.4 / 30.1$ & $6.7 / 5.3$ & $65.8 / 60.2$ \\
\hline \multicolumn{5}{|c|}{ Where does the farmer pour the wash water? } \\
\hline Begin/end & $5.6 / 4.7$ & $33.4 / 17.8$ & $19.3 / 24.4$ & $41.7 / 53.1$ \\
\hline
\end{tabular}

Hazardous waste management: The disposal of packaging for pesticides (glass, bottle, carton, box, bucket, ...) is of particular importance. Figure 8 show that farmers have changed their perception. The farmers collected pesticide packaging and throw into the special tank/container. So the percentage is increasing from $23 \%$ in Begin IPM to $50 \%$ at End IPM. 


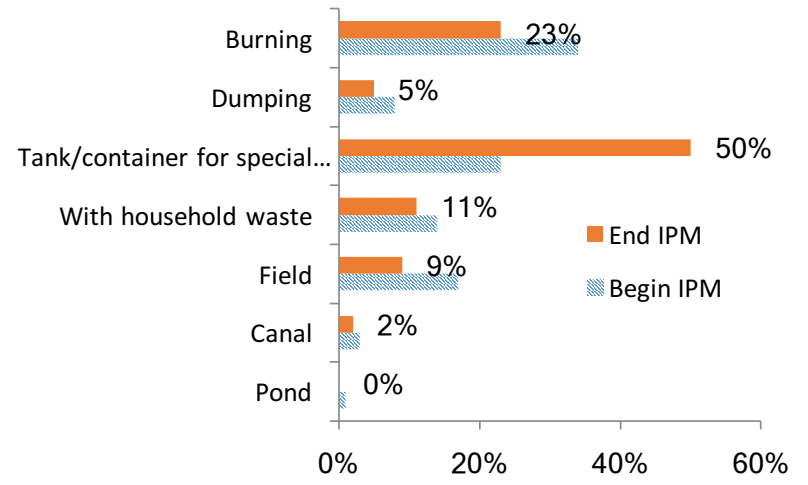

Figure 8. Dumping the pesticide packaging after use

Storage of pesticide: There is generally a positive change of behaviors Begin and End IPM. The percentage of storage of pesticides in the resident house decreased (14.2 \& $5 \%$, Begin \& End IPM respectively), in the storage or special house increased $(55.3 \%$ \& $59.4 \%$, Begin \& End IPM respectively), storage in closed plastic bag and carton, then put behind the residential house $(24.5 \% \& 27 \%$, Begin \& End IPM respectively).

\section{Conclusion}

Starting from the idea is strongly to reduce fertilizer and pesticide in crop production as well as to improve the quality of rice; the IPM program was launched in MD and especially in Hau Giang province in 2014-2017. By using the method of comparing the results between the Begin and End IPM, the important results were reported.

Generally, the pilot results at the End IPM compared to Begin IPM showed that the targets: reduce $50 \%$ pesticides and $10 \%$ fertilizer in the project area, was satisfactory. The farmers are convinced that IPM program can provide economic benefits by reducing costs of production inputs such as fertilizer, herbicide and pesticide (FHP). The seeding amount was not reduced during the pilot phase. The effectiveness of pesticide use is estimated at $80 \%$. In comparison with Begin IPM, at the End IPM in WS season, the cost of FHP decreased by $1,969,000 \mathrm{VND} / \mathrm{ha}$, in AW season decreased by $1,351,000 \mathrm{VND} / \mathrm{ha}$. These results will be further improved in the future, especially the cultivation of high value rice seed such as jasmine 85 . The general awareness of farmers for the packaging and protection of pesticides has increased significantly. Concerning the gender perspective, the role of women in training of rice cultivation techniques and decisionmaking in pest management has also improved significantly. With regard to the environmental aspect, reducing the amount of fertilizers and pesticides means that less is the environmental impact (less waste load flows into groundwater, rivers and streams). With a pesticide reduction of $35-42 \%$ or $0.39-0.49 \mathrm{~kg}$ or liter/ha per crop season, it is estimated that up to $1,000 \mathrm{~kg}$ or litter in 2,610 ha pilot field could not be released into the environment. Hau Giang province has 82,547 ha rice per season and the environemental effect is than very impressive.

Regarding the sustainability of IPM program, one thing to keep in mind is the problem of companies for providing certified rice seed, fertilizer and pesticides (so-called "wealth of companies on the back of the rice producer"). Farmers and companies "manage" rice fields. However, the companies take a large part of the profits from their benefactor. Also the companies try to stimulate demand on fertilizer and pesticides among the farmers by using different measures (import of cheap, but toxic pesticide from China; advertising; bonus program; expandsion of distribution network, later payment for fertilizers and pesticides without bank interest ...). These problems have the opposite effects of this IPM program. Only the market price, policies for food safety, the green barrier in rice trade, high standard of import requirements, and so on can solve these issues and support strongly the IPM program. And so "Vietnam turns back a Tsunami of pesticides" [6].

Acknowledgement: The author thanks the colleagues of Plant Protection Division of DARD of Hau Giang province for the careful implementation of IMP program during the pilot period 2014-2017.

\section{References}

[1] Doan Manh Tuong (2012) Production and export of rice of Vietnam during 1990-2012 (Sản xuất và xuát khẩu lúa gạo của Việt Nam giai đoạn 1990-2012), Cuu Long Delta Rice Research Institute (CLDRRI), Can Tho.

[2] Kotschi, J. (2013) A soiled reputation - Adverse impacts of mineral fertilizers in tropical agriculture (Bodenlos - Negative Auswirkungen von Mineraldüngern in der tropischen Landwirtschaft), Heinrich Böll Stiftung und WWF Deutschland.

[3] Morallo-Rejesus, B. and Rejesus, R.S. (2000) Section 4 - Principles and theory of integrated pest management, FAO

[4] Nguyen Trung Dung (2014) Using fertilizers, herbicides and pesticides in agricultural production in $\mathrm{Vi}$ etnam - Discussion from the perspective of ecological and sustainable economics (Sủ dụng phân bón và thuốc bảo vệ thưc vật trong nông nghiệp ở Việt Nam - Thảo luận ở góc độ kinh tế sinh thái và bền vũng). Journal water resources and environmental engineering 46 (9/2014), p. 108-116, Hanoi.

[5] Norton, G., Mullen, J. (1994) Economic Evaluation of Integrated Pest Management Programs - A Literature Review. Virginia Polytechnic Institute and State University, Blacksburg.

[6] Normile, D. (2014) Vietnam turns back a "Tsunami of pesticides" - Convincing Vietnamese rice farmers to use less pesticide came down to letting them see the benefits for themselves, In Rice Today JanuaryMarch 2014 of IRRI

[7] Report (2017) Baseline survey report at the beginning and end of Integrated Pest Management IPM program WB6 project (Báo cáo kết quả điều tra dĩ liệu co sở đầu kỳ và cuối kỳ chuơng trình IPM thuộc Chuoong trình quản lý dịch hại tổng hợp IPM - Dụ án WB6 Project), Plant protection division of DARD Hau Giang province, Hau Giang. 
[8] Tran Cong Thang (2017) Status of Vietnam Rice Export Quality, Institute of Policy and Strategy for Agriculture and Rural Development, Hanoi.

[9] Tran Viet Nghia (2012) Rice export of Vietnam during the French colonial period 1858-1945 (Xuât khẩu gạo ở Việt Nam thời Pháp thuộc 1858-1945). Journal Nghiên cứu lịch sử (History Study) số 10/2012, Hanoi.

[10] Viet Doan et.al (2017), Wealth on the "back" of rice farmers (Làm giàu trên "lung" người trồng lúa), source: http://tapchimattran.vn/kinh-te/lam-giautren-lung-nguoi-trong-lua-10452.html

[11] Decree 3062/QĐ-BNN-KHCN dated 15.10.2007 reconigzed "Application of advanced techniques of intensive rice cultivation in rice production in some northern provinces".

[12] Decree 942/QĐ-TTg dated 03.07.2017 approving the strategy for development of Vietnam's rice export market in the 2017-2020 period, towards to 2030 . 